\title{
Plasticity of HIV-specific CD8 T cell responses in untreated HIV-1 infection- a step towards a therapeutic vaccine against drug resistance mutations
}

\author{
J Roider, , A Kalteis, T Vollbrecht, L Gloning, R Stirner, N Henrich, JR Bogner, R Draenert
}

From AIDS Vaccine 2012

Boston, MA, USA. 9-12 September 2012

\section{Background}

For a therapeutic HIV-1 vaccine, it should be considered that the immune system has been confronted with a certain viral sequence and mounted CD8 $\mathrm{T}$ cell responses specifically towards the infecting virus. One question is whether the immune system of HIV-infected individuals can create a new response towards a variant epitope in the case of vaccination. To study this in a comparable setting, we addressed the question how frequently a new CD8 T cell response can be generated after the occurrence of a viral escape mutation in its recognized epitope in a population not selected for a certain HLA allele.

\section{Methods}

19 HIV-infected untreated subjects were sampled longitudinally ( $>6$ months. We searched for CD8 T cell responses that declined over the course of untreated infection and sequenced the autologous virus of the early and late time point by RT-PCR. Recognition of wildtype and newly arising sequences was compared in peptide titration assays.

\section{Results}

A total of 30 declining CD8 $\mathrm{T}$ cell responses were studied in detail and viral sequence analyses showed amino acid changes in $25(83 \%)$ of these. Peptide titration assays revealed $12(48 \%)$ viral escape mutations with 2 de-novo responses (17\%). Here the de-novo response showed less effector functions than the original CD8 $\mathrm{T}$ cell response. In addition we identified $5(20 \%)$ shifts in immunodominance. None of the subjects with adaptation to the changing virus carried the HLA alleles B27, B57 or B*5801.

University of Munich, Munich, Germany

\section{Conclusion}

Our results show that CD8 $\mathrm{T}$ cell responses can adapt to the mutations of HIV. However it was limited to only $28 \%$ (7 out of 25) of cases in a cohort not expressing protective HLA alleles.

Published: 13 September 2012

doi:10.1186/1742-4690-9-S2-P284

Cite this article as: Roider et al.: Plasticity of HIV-specific CD8 T cell responses in untreated HIV-1 infection- a step towards a therapeutic vaccine against drug resistance mutations. Retrovirology 2012 9(Suppl 2):P284.
Submit your next manuscript to BioMed Central and take full advantage of:

- Convenient online submission

- Thorough peer review

- No space constraints or color figure charges

- Immediate publication on acceptance

- Inclusion in PubMed, CAS, Scopus and Google Scholar

- Research which is freely available for redistribution

Submit your manuscript at www.biomedcentral.com/submit 